\title{
ANALYSIS OF STATIC AND DYNAMIC DEFORMATION MODULUS
}

\author{
Mindaugas MIKOLAINIS ${ }^{\mathrm{a}}$, Marijus USTINOVIČIUS ${ }^{\mathrm{b}}$, \\ Danute SLIŽYTÉc, Tatyana ZHILKINA ${ }^{\mathrm{d}}$ \\ ${ }^{a} S P$ „Baltijos inžineriniai sprendimai“, Laisvès 3-16, LT-97147 Kretinga, Lithuania \\ ${ }^{b} A B$ „Markuciai Sverige“ Box 37 SE-125 21 Älvsjö, Stockholm Sweden \\ ${ }^{c}$ Vilniaus Gedimino technikos universitetas, Statybos fakultetas, Geotechnikos katedra, \\ Sauletekio al. 11, LT-10223 Vilnius, \\ Lithuania \\ ${ }^{d}$ Moscow State University of Civil Engineering (National Research University), \\ Yaroslavskoye shosse 26, 129337 Moscow, Russia
}

Received 02 May 2016; accepted 10 June 2016

\begin{abstract}
This article summarises dynamic deformation modulus correlation with second reload of static plate load test results for an even thickness soil strata layer. An analysis of execution and result interpretation of both static deformation modulus and dynamic deformation modulus is provided also. Different correlations between the two modulus according to different authors are provided. Since dynamic plate load test is not regulated in Lithuania as a soil compaction contron method, a few dynamic plate load tests and static plate load tests were executed in order to compare compaction results. The additional experiments for dynamic plate load tests in different depths were executed which showed that deformation modulus is dependant on depth of test execution, thus it is worthwile to mention to be cautious on compaction results in trenches.
\end{abstract}

Keywords: static plate load test, dynamic plate load test, deformation modulus, compaction control.

\section{Introduction}

Dynamic plate load (DPL) tests in road construction are not used very often, since dynamic plate load test is not accepted as an official compaction method in Lithuania (Bertulienè 2011; Lietuvos automobilių... 2004). Thus aforementioned test is rarely used as an official compaction test and is used in sites where minor compaction is permissible (for example: sidewalk zones, trenches, etc.) where static plate load (SPL) test would be difficult to execute, or where loads are light. e.g., pedestrian sidewalks or residential floors. In order to use dynamic plate load tests for road base compaction tests it is needed to have a reliable comparison between dynamic deformation modulus and second load static plate deformation modulus. New dynamic plate load test values and their comparison with static plate load test values would help to evaluate compaction quality in both methods, thus helping to gain credibility of DPL tests (Tompai 2008; Bertulienè 2014). It is worth to mention that different countries had done these experiments and the analyses of results gave a mutual result showing that there is a relation between DPL and SPL tests, but they differ when applying them on different soil layers (Tompai 2008; Bertulienè et al. 2010). When the compaction quality of soil is tested as usualy the correlation relationship between $E_{v d}$ and $E_{V 2}$ is indicated, but these cases are often mentioned in literature with postscript: 'for information purposes

Corresponding author:

D. Sližytė E-mail: danute.slizyte@vgtu.lt 
only, no guarantee of information correctness' (Zorn instruments 2004). Herefore, the study was to verify whether relationships between $E_{v d}$ and $E_{v 2}$ which are found in literature can be applied to uniform (poorly graded) fine sand and how $E_{v d}$ depends on surcharges near the plate during the DPL test.

\section{Dynamic deformation modulus evaluation according to dynamic plate load test}

Theoretically if one wants to evaluate compressibility it is considered that a soil deforms as an ideally homogenical, isotropical material (Smoltczyk 2002; Zorn instruments 2004). Concentrated force $P$ is loading load plate, and cause of this load plates settlement is $s$. This elasticity modulus is taken from theory of elasticity and can be evaluated as follows:

$$
E=\frac{1-v^{2}}{2} \cdot \frac{P}{r \cdot s} ;
$$

Here $E$ - modulus of elasticity, MPa, $v$ - Poissons ratio, $r$ - radius of plate, $\mathrm{m}, P$ - force at plate workplane, $\mathrm{MN}$.

It is assumed that contact stresses under load plate are even and equal:

$$
\sigma_{0}=\frac{P}{\pi \cdot r^{2}} .
$$

If assuming that soil Poisson's ratio is $v=0.212$ and that soil is elastic, formula can be represented as a differential equation:

$$
E_{v}=1.5 \cdot r \cdot \frac{\Delta \sigma_{0}}{\Delta s} .
$$

It is important that this equation is derrivative out of formula (1) where soil is elastic and this is true only when density ratio (actual density versus Proctor optimal density $\left.-D_{p r}, \%\right)$ is large.

When analysing dynamic deformation modulus it is assumed that inertial forces and scale factor is not evaluated. Maximal stress to base is equal, i.e. not dependant from soil type, properties $\sigma_{0 \text { max }}=0.1 \mathrm{MPa}$, plate radius $150 \mathrm{~mm}$. When these entered to (3), we get:

$$
E_{v D}(M P a)=\frac{22.5}{s_{\max }(\mathrm{mm})} .
$$

Here $s_{\max }$ - plate settlement (average of three tests) from dynamic load.

Acording this equation (4) $E_{v d}$ is calculated during DPL test (Zorn instruments 2004).

\section{Soil static plate load test according0 to LST 1360.5:1995}

Load to soil is increased incrementally by $0.02 \mathrm{MPa}$. This incrementation is around 10 . When maximum value is reached, load plate is unloaded to $50 \%$ of maximal loading, then to $25 \%$ of maximal loading, then it is totally unloaded. When load plate is fully unloaded an additional secondary loading is executed, but it is loaded up to $9^{\text {th }}$ load incrementation value from the previous load. Two deformation modules $E_{v 1}$ and $E_{v 2}$ are evaluated, respectivelly for first load curve and for second load curve (Fig. 1).

In order to evaluate modulus of deformation, a regression curve has to be solved, which is defined as follows

$$
s=a_{0}+a_{1} \cdot \sigma_{0}+a_{2} \cdot \sigma_{0}^{2} .
$$

Here $\sigma_{0}$ - soil stress under load plate, $s$ - load plate settlement, $\mathrm{mm} ; a_{0}, a_{1}, a_{2}$ - second degree constants, which can be found from the following equations:

$$
\begin{aligned}
& a_{0} \cdot n+a_{1} \sum_{i=1}^{n} \sigma_{0 i}+a_{2} \sum_{i=1}^{n} \sigma_{0 i}^{2}=\sum_{i=1}^{n} s_{i} ; \\
& a_{0} \sum_{i=1}^{n} \sigma_{0 i}+a_{1} \sum_{i=1}^{n} \sigma_{0 i}^{2}+a_{2} \sum_{i=1}^{n} \sigma_{0 i}^{3}=\sum_{i=1}^{n} s_{i} \cdot \sigma_{0 i} ; \\
& a_{0} \sum_{i=1}^{n} \sigma_{0 i}^{2}+a_{1} \sum_{i=1}^{n} \sigma_{0 i}^{3}+a_{2} \sum_{i=1}^{n} \sigma_{0 i}^{4}=\sum_{i=1}^{n} s_{i} \cdot \sigma_{0 i}^{2} .
\end{aligned}
$$

The first and the secondary load curves from which deformation modulus is calculated connecting tangent values of curve values $0,3 \sigma_{0 j \text { max }}$ and $0,7 \sigma_{0 j \max }$ are analysed:

$$
E_{v j}=1.5 \cdot r \cdot \frac{\Delta \sigma_{0}}{a_{1}+a_{2} \cdot \sigma_{0 j \max }} .
$$

Here $\Delta \sigma_{0}$ - load plate contact stress difference, MPa; $a_{1}, a_{2}$ - constants found from equation $6 ; \sigma_{0 j \max }-j$ maximum stresses under load plate, $\mathrm{MPa}$.

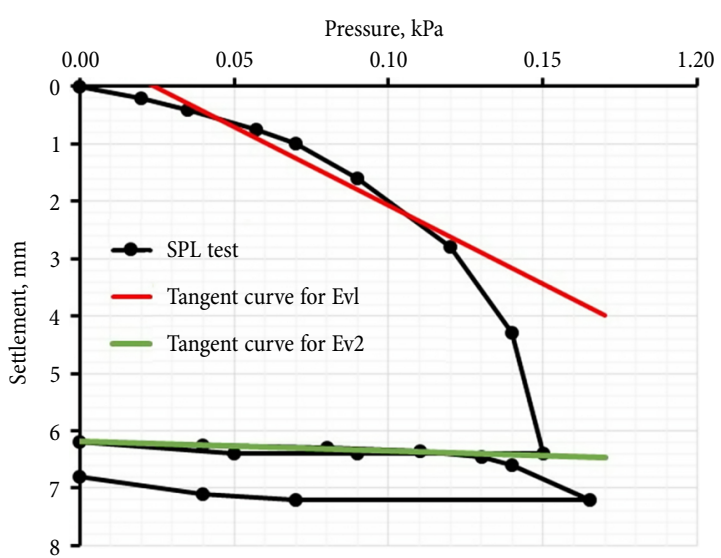

Fig. 1. Pressure settlement curve from SPL test 
Table 1. $E_{V 2}$ and $E_{V D}$ correlations.

\begin{tabular}{|c|l|}
\hline$E_{V 2}$ and $E_{V D}$ correlation & \multicolumn{1}{c|}{$\begin{array}{c}\text { Limitations of formulae } \\
\text { application, author }\end{array}$} \\
\hline$E_{V 2}=1.923 \cdot E_{V D}-17.5$ & $\begin{array}{l}\text { „Baksay formula } \\
\text { (Measurement of load... 1995) }\end{array}$ \\
\hline$E_{V 2}=1.58 \cdot E_{V D}$ & $\begin{array}{l}\text { Coarse and fine sands } \\
\text { (Tompai 2008). }\end{array}$ \\
\hline$E_{V 2}=1.30 \cdot E_{V D}$ & Silts (Tompai 2008) \\
\hline$E_{V 2}=1.69 \cdot E_{V D}$ & $\begin{array}{l}\text { Crushed stone, lime stabilised } \\
\text { soils (Tompai 2008) }\end{array}$ \\
\hline$E_{V 2}=600 \cdot \ln \left(\frac{300}{300-E_{V D}}\right)$ & Zorn instruments 2004 \\
\hline
\end{tabular}

Since dynamic load plate test is simpler and faster, the experiments were started to implement since 1995 (Measurement of load... 1995) in order to find relations between secondary load deformation modulus $E_{v 2}$ and dynamic deformation modulus $E_{v d}$. Table 1 represents summary of different author experiments and relations between the two.

Recommended values applicable for Lithuania see in Figure 2.

Ustinovičius (2015) has done subgrade deformation modulus tests in Vilnius Intermodal terminal. Subgrade was prepared and densified with uniform fine sand strata (LST EN ISO 14688-2, LST EN 9331:2002). 30 static plate load and dynamic plate load tests were done by using statical beam "Frowag" and dynamic plate load "Zorn ZSG - 02". Results with recommended correlation values in Lithuania are presented in Figure 3.

A comparison of the experimental data (Fig. 4) indicated that in Lithuania the $E_{V D}$ to $E_{V 2}$ conversion values (Zorn instruments 2004; Lietuvos automobiliu ... 1995) used for uniform (poorly graded) fine sand is too high. To such soils the dependencies of „Baksay formula" and Tompa 2008 for the coarse and fine soils suit better. In a very important objects formation of dependence according the results of tests in Situ is recommended.

\section{Dynamic deformation modulus dependence on surcharge}

Dynamic plate load test can be used also in trench. It is known that during static plate load test static deformation module $E_{V 2}$ of $2^{\text {nd }}$ loading obtained in trench is larger than $E_{V 2}$, then the test is executable with the same conditions from the ground surface (Paulmich

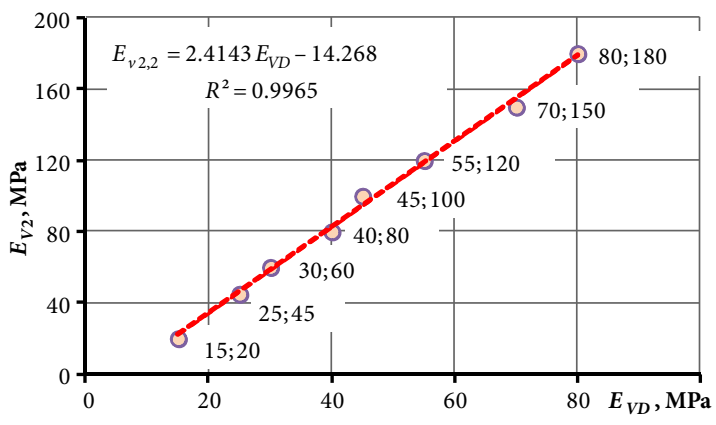

Fig. 2. Recommended approximate dynamic plate load test deformation modulus Evd convertion to static plate load test deformation modulus Ev2 values (Lietuvos automobilių... 1995)

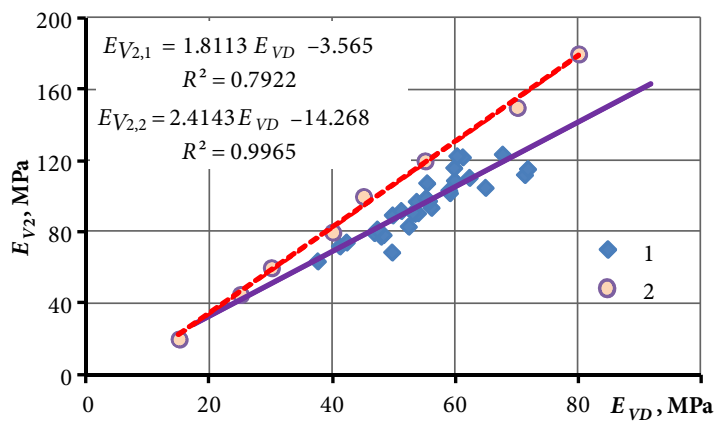

Fig. 3. Test results (Ustinovičius 2015), combined with Lithuania recommended conversion values. 1 - experimental values, 2 - values according to (Lietuvos automoblių ... 1995)

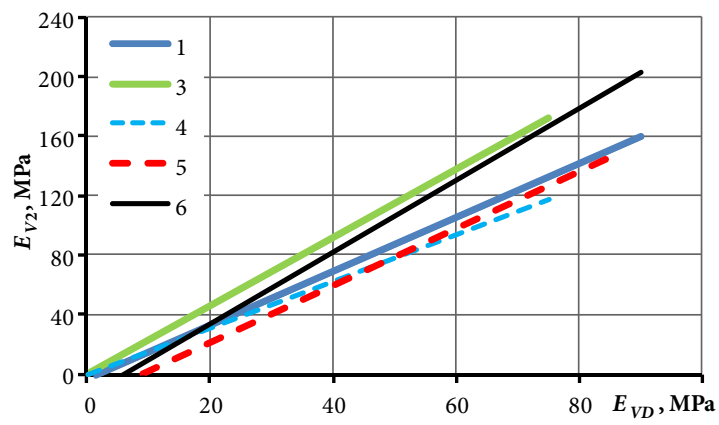

Fig. 4. $E_{V 2}$ and $E_{V D}$ dependences. 1 - according to the test results; 2 - Baksay formula (Measurement of load... 1995); 3 coarse and fine soils, (Tompa 2008), 4 - Zorn instruments 2004; 5 - Lietuvos automobilių ... 1995

2004). Ascertaining whether the dynamic plate load test results for surcharge of soil are affected by the results of the tests the experiment was carried out. Surcharge around to the plate simulates the soil prism of trench. Test scheduled equivalent trench depth is equal

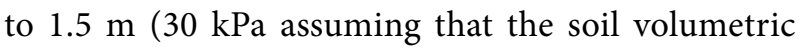
weight of $20 \mathrm{kN} / \mathrm{m} 3)$.

An area in which the natural soil is homogeneous and of natural density was selected, and the tests were carried out in three rows, separated from each other by $2 \mathrm{~m}$ (Fig. 5 ). 
Dynamic load plate test in the above place for determination of soil dynamic deformation modulus $\left(E_{V D}\right)$ was carried out. Close distance $(15-30 \mathrm{~cm})$, but not in the same place load blocks $(5 \mathrm{kPa})$ on two floors $(10 \mathrm{kPa})$ were fixed on four sides around the plate (symmetric surcharge). The plate during the test is left between the load blocks (Fig. 6). The test objective was to distract the testing locations so that one test soil compaction should not affect other test results.

The test plan is shown in Figure 5.

The load is therefore increased up to $20 \mathrm{kPa}$ and then to $30 \mathrm{kPa}$, by the same procedure. For a maximum of 24 bricks at 6 in the floor should be used in total. The tests' results are shown in Table 2.

Experimental data show, that the soil is very loose. According the graphic (Fig. 7) can be seen that when the increase surcharge values with equal intervals (intervals of $10 \mathrm{kPa}$ ) dynamic deformation modulus increases more rapidly, in other words, the curve slope increases. From the experimental data can be determined curve function.

Acceptance curve function $b$ successive power curve. This polynomial is represented by LevenbergMarquard minimization method (Marquardt 1979):

$$
E_{V D}=a \cdot H^{b}+c .
$$

According the said method of calculation, we get the polynomial constants $a, b, c$. Then the expression of prediction of dynamic deformation modulus $(\mathrm{MPa})$ is:

$$
E_{V D}=0.726 \cdot H^{2.443}+2.971 \text {. }
$$

There the relative depth:

$$
H=\frac{p}{\gamma}
$$

Here $p$ - surcharge, $\mathrm{kPa}, \gamma$ - soil unit weight, taken $20 \mathrm{kN} / \mathrm{m}^{3}$, because soil above tested surface must be compacted.

The experimental data and theoretical relationship between the $E_{V D}$ and the excavation depth (or surcharge) presented in Figure 8.

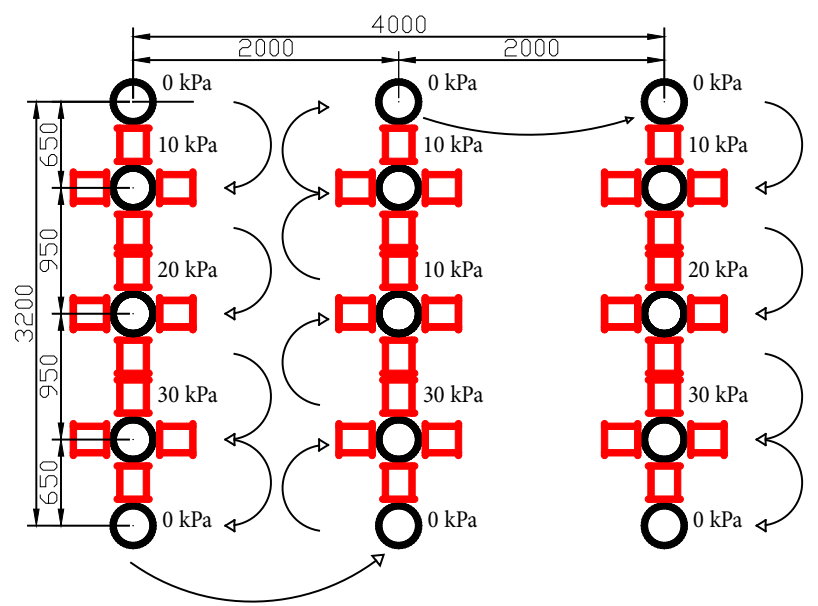

Fig. 5. Experiment plan (distances in $\mathrm{mm}$ )

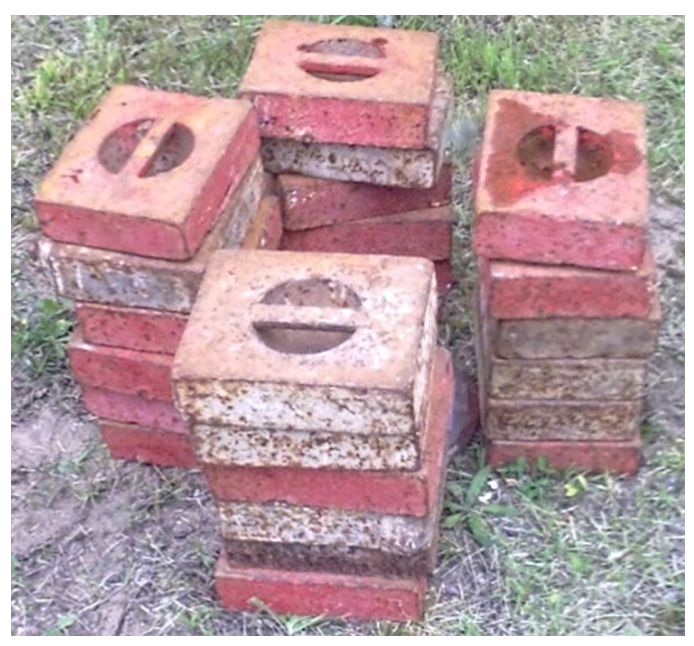

Fig. $6.30 \mathrm{kPa}$ surcharge around dynamic plate

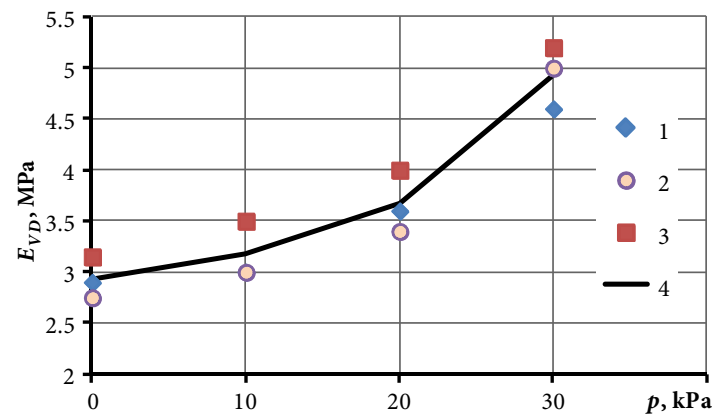

Fig. 7. Dynamic deformation module and surcharge dependence experimental data. $1,2,3$ - test data from $1^{\text {st }}, 2^{\text {nd }}$ and $3^{\text {rd }}$ test site, 4 - mean values of dependency

Table 2. Experiment data (Mikolainis 2012)

\begin{tabular}{|c|c|c|c|c|c|}
\hline Dynamic deformation module $E_{V D}$ under surcharge & $0 \mathrm{kPa}$ & $10 \mathrm{kPa}$ & $20 \mathrm{kPa}$ & $30 \mathrm{kPa}$ & $0 \mathrm{kPa}$ \\
\hline Test site No. & 1 & 2 & 3 & 4 & 5 \\
\hline 1 & $2.9 \mathrm{MPa}$ & $3.0 \mathrm{MPa}$ & $3.6 \mathrm{MPa}$ & $4.6 \mathrm{MPa}$ & $2.9 \mathrm{MPa}$ \\
\hline 2 & $2.4 \mathrm{MPa}$ & $3.0 \mathrm{MPa}$ & $3.4 \mathrm{MPa}$ & $5.0 \mathrm{MPa}$ & $3.1 \mathrm{MPa}$ \\
\hline 3 & $3.3 \mathrm{MPa}$ & $3.5 \mathrm{MPa}$ & $4.0 \mathrm{MPa}$ & $5.2 \mathrm{MPa}$ & $3.0 \mathrm{MPa}$ \\
\hline
\end{tabular}




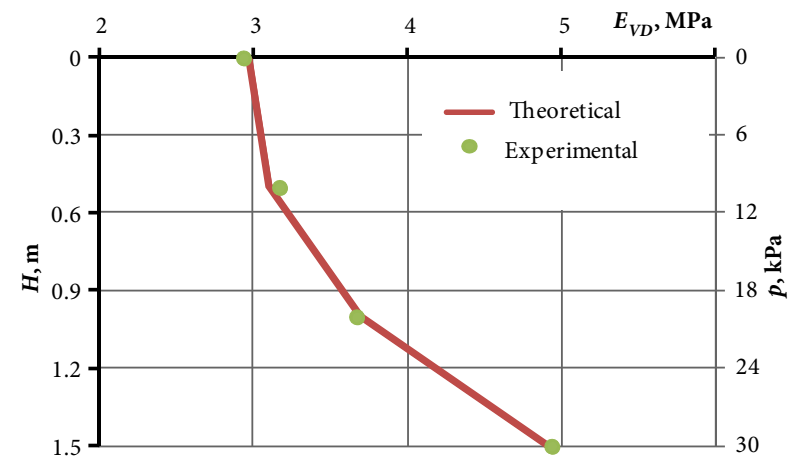

Fig. 8. Comparison of empirical equation and experimental data

\section{Conclusions}

For uniform (poorly graded) fine sand used $E_{V D}$ to $E_{V 2}$ conversion values according Zorn instruments (2004) and (Lietuvos automobiliu ... 1995) are too high, making it unusable.

For uniform (poorly graded) fine sand $E_{V D}$ to $E_{V 2}$ conversion values are better suited from the dependencies of „Baksay formula" (Measurement of load) and Tompa (2008) for the coarse and fine soils. In a very responsible objects recommended formation of dependence according the results of in Situ tests.

It was found that an $E_{V D}$ value depends on surchage around plate during test, its rises with surcharge (or increased of depth).

The proposed empirical regression equation evaluates deformation module size at surcharge. It applies to the measurement of the compaction of trenches. However, the suggested relationship for only a very loose sand. In order to evaluate the deformation of the module dependency surcharge, should be performed with a variety of different parameters (granulometry and state of compaction).

\section{References}

Bertulienè, L. 2011. Automobiliu keliu konstrukcijos pagrindo sluoksniu stiprumo nustatymo metodu vertinimas, tyrimai ir taikymas [Assessment, research and use of methods for determining the strength of base courses of road pavement structure]: Doctoral dissertation. Vilnius: Technika (in Lithuanian). $147 \mathrm{p}$.
Bertulienė, L. 2014. Research of methods for determining the strength of subgrade of road pavement, in 9th International Conference „Environmental Engineering“, 22-23 May 2014, Vilnius, Lithuania: selected papers. ISSN 2029-7092.

Bertulienė, L. Laurinavičius, A. Vaitkus, A. 2010. Research and evaluation of methods for determining deformation modulus of a base course of road pavement, The Baltic Journal of Road and Bridge Engineering 5(2): 110-115. http://dx.doi.org/10.3846/bjrbe.2010.16

Lenke, L.; McKeen, R. G. (Eds.). 2001. Evaluation of mechanical stiffness gauge for compaction control of granular media.Report No. NM99MSC-07.2, New Mexico State Highway and Transportation Department Research Bureau. 55 p.

Lietuvos automobilių kelių direkcija. 1995. Automobiliu kelių sankasos ir pagrindo bandymo dinaminiu prietaisu instrukcija. Vilnius. $12 \mathrm{p}$.

Lietuvos automobilių kelių direkcija. 2004. Automobiliu keliu žemès sankasos irrengimas. Statybos taisykles. ST 188710638.06:2004. Vilnius: 109 p.

LST EN ISO 14688-2:2004. Geotechnical investigation and testing - Identification and classification of soil - Part 2: Principles for a classification (ISO 14688-2:2004).

LST EN 933-1:2002. Užpildu geometriniu sąvybiu nustatymo metodai. 1 dalis. Granuliometriness sudèties nustatymas. Sijojimo metodas. Vilnius: 2002. 11 p.

LST 1360.5:1995. Automobiliu keliu gruntai. Bandymo metodai. Bandymas štampu. Vilnius, 1995. 17 p.

Marquardt, D. 1979. An algorithm for least-squares estimation of nonlinear parameters, SIAM Journal on Applied Mathematics 431-441.

Measurement of load bearing capacity with lightweight deflectometers (Wemex/ZFG). 1995. Institute for Transport Sciences. Research report.

Mikolainis, M. 2012. Požeminiu polimeriniu talpu sąveika su gruntu [Soil-structure interaction of buried polymer vessels]: Master's Thesis. Vilnius Gediminas Technical University, Vilnius, Lithuania (in Lithuanian).

Paulmich, I. 2004. Numerical simulation of statical and dynamical compaction control methods on layered half spaces by means of boundary element method: Master's Thesis. Vienna Technical University, Vienna, Austria.

Smoltczyk, U. 2002. Geotechnical engineering handbook. Darmstadt: Betz - Druck GmbH. 2055 p.

Tompai, Z. 2008. Conversation between static and dynamic load bearing capacity moduli and introduction of dynamic target values, Civil Engineering 52(2): 97-102.

Ustinovičius, M. 2015. Investigation of soil compaction quality parameters: Master's Thesis. Vilnius Gediminas Technical University, Vilnius, Lithuania (in Lithuanian).

Zorn instruments. 2004. Light drop-weight tester ZFG-02 operating manual. Zorn. 30 p. 
Mindaugas MIKOLAINIS. Freelance geotechnical engineer of Baltijos Inžineriniai sprendimai. Fields of research and work: heavy construction, foundation design, construction on weak soils, highway engineering, engineering with geosynthetics. He have been in the field not only in Lithuania but also abroad practicing geotechnical engineering on major Austrian geotechnical consulting firm - 3P Geotechnik as well as using his knowledge on field in drilled shaft foundations, deep excavations, highway engineering, undergound construction, and offshore engineering in Boston and New York, USA at SKANSKA USA Civil.

Marijus USTINOVIČIUS. Bachelor's degree at the Steel and Timber department of Vilnius Gediminas Technical University. Master`s degree at the Geotechnical Department of Vilnius Gediminas Technical University. Work experience: 2009-2015 JSC "Fegda" deparment of Road Research Laboratory. 2015-till now, Construction Engineer on SC "Markuciai Sverige" Sweden. Currently leads the "Munksjostaden" project (Constructions of the apartments blocks) in Sweden, Jonkoping.

Danutė SLIŽYTĖ. Dr, Assoc. Prof. of the Geotechnical Department of Vilnius Gediminas Technical University. Fields of research: foundation underpinning, relationship between ground and structures, estimation of soil mechanical properties, pile foundation.

Tatiana ZHILKINA Dr., Assoc. Prof. of Moscow State University of Civil Engineering. Fields of research: soil stabilization, foundation underpinning, estimation of soil mechanical properties, pile foundation. Published 39 articles. 